\title{
Pengaruh Kemampuan dan Motivasi Kerja Terhadap Kinerja Pegawai Negeri Sipil pada Dinas Pendidikan dan Kebudayaan Provinsi Nusa Tenggara Barat
}

\author{
Agustine Prokaningsih Sumuweng', Manggaukang ${ }^{2}$ \\ ${ }^{1}$ Administrasi Publik, Universitas Terbuka Mataram, tine.sumuweng74@gmail.com \\ ${ }^{2}$ Perpustakaan dan Kearsipan Provinsi NTB, daenggaumangga@yahoo.co.id
}

INFO ARTIKEL
Riwayat Artikel:
$\begin{aligned} & \text { Diterima: } 20 \quad \text { Agustus } \\ & 2020 \\ & \text { Disetujui: } 30 \text { September } \\ & 2020\end{aligned}$

\section{Kata Kunci:}

Kemampuan

Motivasi Kerja

Kinerja

Pegawai Negeri Sipil

\section{A. LATAR BELAKANG}

Setiap Organisasi semakin dituntut untuk dapat memberikan nilai tambah yang lebih dibandingkan dengan apa yang diharapkan jika dihubungkan dengan perkembangan yang semakin menekan organisasi untuk selalu berubah. Nilai tambah tersebut dapat terlihat dari

\begin{abstract}
Abstrak: Setiap organisasi mengharapkan setiap anggotanya memiliki kinerja yang baik dalam bekerja, salah satunya di Dinas Pendidikan dan Kebudayaan Provinsi NTB. Tugas pokoknya adalah melaksanakan urusan pendidikan dan kebudayaan dengan menyelenggarakan fungsi perumusan kebijakan, pelaksanaan evaluasi dan pelaporan. Kemampuan pegawai yang tergambar melalui kualifikasi pendidikan dari pekerjaannya memperlihatkan bahwa spesifikasi mereka masih belum sesuai dengan bidang pekerjaan. Selain itu, tingkat absensi pegawai masih tinggi karena masih banyak beberapa pegawai masih tinggi karena masih banyak beberapa pegawai yang sering tidak masuk kerja tanpa keterangan. Penelitian ini bertujuan untuk mengukur dan menganalisis signifikansi pengaruh dari Kemampuan terhadap Kinerja Pegawai, mengukur dan menganalisis signifikansi pengaruh dari Motivasi Kerja terhadap Kinerja Pegawai, dan mengukur dan menganalisis dominasi pengaruh di antara variabel Kemampuan dan Motivasi Kerja terhadap Kinerja Pegawai. Jenis penelitian adalah penelitian asosiatif kausal. Populasi dalam penelitian ini adalah 128 orang. Alat yang dipakai sebagai pengumpulan data berupa kuesioner. Analisa data menggunakan analisis regresi linier berganda. Hasil penelitian ini menunjukkan bahwa : terdapat pengaruh yang signifikan secara parsial dari Kemampuan terhadap kinerja pegawai pada Dinas Pendidikan dan Kebudayaan Provinsi Nusa Tenggara Barat, terdapat pengaruh yang signifikan secara parsial dari motivasi kerja terhadap kinerja pegawai pada Dinas Pendidikan dan Kebudayaan Provinsi Nusa Tenggara Barat, dan Kemampuan memiliki pengaruh yang dominan terhadap kinerja pegawai pada Dinas Pendidikan dan Kebudayaan Provinsi Nusa Tenggara Barat.
\end{abstract}

ABSTRAK

\begin{abstract}
Each organization expects every member to have a good performance at work, one of which is in the NTB Provincial Education and Culture Office. Its main task is to carry out educational and cultural affairs by carrying out policy formulation, evaluation, and reporting. As reflected in the academic qualifications of their work, the ability of employees shows that their specifications are still not by the field of work. Also, the employee absentee level is still high because of many employees are still high. After all, there are still many employees who often do not come to work without information. This study aims to measure and analyze the significance of the influence of Ability on Employee Performance, measure and analyze the importance of the effect of Work Motivation on Employee Performance, and measure and analyze the dominance of influence between Ability and Work Motivation on Employee Performance. This type of research is a causal associative research. The population in this study was 128 people. The tool used as data collection was a questionnaire-data analysis using multiple linear regression analysis. The results of this study indicate that: there is a partially significant influence of ability on employee performance at the West Nusa Tenggara Province Education and Culture Office, there is a partially significant effect of work motivation on employee performance at the West Nusa Tenggara Province Education and Culture Office, and ability has a dominant influence on the performance of employees at the Education and Culture Office of West Nusa Tenggara Province.
\end{abstract}

kinerja yang ditunjukkan oleh anggota-anggota dalam organisasi. Dalam menjalankan setiap peran dan fungsinya, setiap anggota organisasi harus terlibat secara aktif di dalamnya. Hal ini sesuai dengan definisi organisasi itu sendiri dimana terdiri dari dua orang atau lebih yang bekerja untuk mencapai tujuan organisasi. Hasil dari pekerjaan anggota organisasi dapat terlihat 
sebagai kinerja. Kinerja dapat dimaknai lebih luas tidak hanya terpaku pada hasil kerja, namun di dalamnya berkaitan dengan proses penyelesaian pekerjaan diselesaikan.[1] Kinerja sebagai keluaran dari pekerjaan yang sangat berkaitan dengan tujuan organisasi, adanya kepuasan dan memberikan dampak nyata terhadap perubahan ekonomi.[2] Kinerja dapat dikatakan sebagai hal yang sangat berkaitan dengan proses dan pencapaian hasil pekerjaan. Kinerja adalah hasil dari suatu pekerjaan karyawan baik yang dapat diukur secara kualitas maupun kuantitas sesuai dengan peran dan fungsinya di dalam organisasi.[3][4]

Setiap organisasi mengharapkan setiap anggotanya memiliki kinerja yang optimal dalam melaksanakan pekerjaan. Salah satunya adalah Dinas Pendidikan dan Kebudayaan Provinsi NTB. Salah satu tugas pokoknya adalah melaksanakan urusan pendidikan dan kebudayaan dengan menyelenggarakan fungsi perumusan kebijakan, melaksanaan kebijakan, pelaksanaan evaluasi dan pelaporan. Dalam pelaksanaan target kerja, Dinas Pendidikan dan Kebudayaan Provinsi NTB masih dapat dikatakan memiliki banyak hambatan. Hal ini dapat terlihat dari hasil kerja pegawai tahun 2019 masih sangat rendah karena berada pada persentase pencapaian rata-rata $10 \%$. Kinerja individu dapat menggambarkan kinerja organisasi oleh sebab itu tentu saja capaian ini menunjukkan kinerja organisasi yang masih rendah. Capaian yang masih rendah ini dapat dipengaruhi oleh berbagai faktor. Menurut Davis, faktor yang mempengaruhi pencapaian kinerja salah satunya adalah faktor kemampuan (ability). Kemampuan pada umumnya diartikan sebagai kecakapan dan keterampilan. Kemampuan kata dasarnya adalah kompeten yang berarti cakap, mampu atau terampil. Kemampuan dan keterampilan memainkan peran penting dalam perilaku dan kinerja individu.

Kemampuan merupakan sebuah bawaan yang dapat dipelajari yang menunjukkan sikap dan perilakunya dalam melaksanakan sesuatu baik yang bersifat mental maupun fisik. Kemampuan juga diartikan sebagai sifat biologikal dan yang bisa dipelajari yang memungkinkan seseorang melakukan sesuatu, baik bersifat mental maupun fisik.[5] Kemampuan merupakan perilaku yang mendasar dari seseorang yang dapat berpengaruh secara langsung terhadap kinerja.[6] Kemampuan adalah suatu bakat yang dimiliki seseorang dalam melaksanakan pekeraan yang bersifat fisik maupun mental.[7] Artinya bahwa kemampuan seorang pegawai merupakan apa yang ada di dalam dirinya dan merupakan potensi untuk menyelesaikan pekerjaannya baik yang bersifat tugas fisik maupun yang bersifat tugas mental. Seorang pegawai harus memiliki Kemampuan yang baik dalam menunjang pekerjaannya berhasil atau untuk berkinerja dengan baik.

Untuk membedakan karyawan yang memiliki kinerja yang tinggi dengan yang berkinerja rendah, dapat diidentifikasi faktor-faktor penting dari kemampuan seorang pekerja yaitu : (1) kemampuan mental yang berkaitan dengan tingkat kecerdasan yang dimiliki oleh seseorang yang dapat dibagi ke dalam beberapa subkategori seperti kelancaran, pemahaman yang bersifat verbal, daya ingat maupun orientasi. (2) Intelegensi emosi (emotional inteligence) yang berkaitan dengan tingkat kemampuan seseorang untuk menyadari perasaan, mengelola emosi, memotivasi diri, mengekspresikan empati, dan menangani relasi dengan pihak lain. (3) Tacit knowledge yang merujuk pada pengetahuan praktis yang diperoleh karyawan melalui pengamatan dan pengalaman langsung.[7][8] Kemampuan memiliki hubungan yang nyata terhadap kinerja pekerjaan, sehingga seorang manajer harus berusaha menyesuaikan kemampuan seseorang dengan kebutuhan pekerjaan. Apabila kemampuan dengan pekerjaannya sudah sesuai tentu saja akan dapat menghasilkan kinerja yang diharapkan oleh organisasi.

Adapun gambaran kemampuan kerja yang dapat dilihat dari kualifikasi pendidikan dengan pekerjaan pada Dinas Pendidikan dan Kebudayaan Provinsi NTB dapat dilihat bahwa kualifikasi pendidikan pegawai masih banyak yang belum sesuai dengan tugas pokok dan fungsi yang harus dilaksanakannya. Hasil kerja yang baik sangat ditopang oleh kemampuan seseorang dalam bekerja yang dapat dilihat dari kesesuaian kualifikasi dengan pendidikannya. Hal ini sejalan dengan pendapat lain menjelaskan bahwa keberhasilan dan peningkatan hasil kerja seorang pegawai dapat dipengaruhi oleh faktor karakteristik individu yang salah satunya adalah tingkat pendidikan.[9] [10]

Selain faktor motivasi, faktor lainnya yang mempengaruhi kinerja adalah motivasi. Menurut Davis , pencapaian dari kinerja seseorang dapat dipengaruhi oleh faktor motivasi (motivation). Motivasi merupakan dorongan yang dimiliki oleh seseorang di dalam dirinya, yang menggerakkannya untuk bekerja dan berusaha menghasilkan sesuatu. Pengertian ini memperlihatkan bahwa motivasi dapat menunjukkan bagaimana seseorang mengarahkan dirinya. Manajer memiliki peran besar dalam menjaga dan mengarahkan perilakunya. Karyawan yang memiliki motivasi memiliki kecendrungan untuk menghasilkan pekerjaan dengan kriteria dan kualitas yang tinggi.[5] [11]

Adapun gambaran motivasi pegawai Dinas Pendidikan dan Kebudayaan Provinsi NTB dapat dilihat dari tingkat absensi dalam bekerja, sebagaimana ditujukan pada tabel berikut ini.

\section{Tabel 1}

Gambaran Absensi Pegawai Dikbud NTB tahun 2019

\begin{tabular}{llccccccc}
\hline \multirow{2}{*}{ No } & \multirow{2}{*}{ Bln } & \multirow{2}{*}{ Jlh } & \multicolumn{5}{c}{ Total Absensi Kehadiran } \\
\cline { 4 - 9 } & & Pgw & $\begin{array}{c}\text { Saki } \\
\text { t }\end{array}$ & $\begin{array}{c}\text { Iji } \\
\text { n }\end{array}$ & $\begin{array}{c}\text { Cut } \\
\text { i }\end{array}$ & $\begin{array}{c}\text { T } \\
\text { B }\end{array}$ & $\begin{array}{c}\text { T } \\
\text { D }\end{array}$ & $\begin{array}{c}\text { Non } \\
\text { Ket. }\end{array}$ \\
\hline 1 & Jan. & 128 & 9 & 3 & 6 & & 11 & - \\
\hline
\end{tabular}




\begin{tabular}{clllllll}
2 & Feb. & 128 & 11 & 2 & 2 & 49 & - \\
3 & Mar. & 128 & 8 & 8 & 4 & 63 & - \\
4 & Apr. & 128 & 5 & 2 & 1 & 76 & - \\
5 & Mei & 128 & 8 & 8 & 2 & 25 & - \\
6 & Juni & 128 & 4 & 5 & 1 & 52 & - \\
7 & Juli & 128 & 11 & 18 & 1 & 48 & 23 \\
8 & Agust & 128 & 4 & 10 & 2 & 59 & 22 \\
\multicolumn{5}{l}{ Sumber : Bagian Umum Kepegawaian Dikbud NTB 2019 }
\end{tabular}

Berdasarkan pada tabel 1 di atas, dapat diketahui bahwa tingkat absensi pegawai masih tinggi karena masih banyak beberapa pegawai yang sering tidak masuk kerja dengan berbagai alasan. Termasuk yang tidak masuk kerja tanpa keterangan. Adapun tujuan dalam penelitian ini adalah Pertama, untuk mengukur dan menganalisis signifikansi pengaruh dari Kemampuan terhadap Kinerja Pegawai Negeri Sipil pada Dinas Pendidikan dan Kebudayaan Provinsi Nusa Tenggara Barat. Kedua, untuk mengukur dan menganalisis signifikansi pengaruh dari Motivasi Kerja terhadap Kinerja Pegawai Negeri Sipil pada Dinas Pendidikan dan Kebudayaan Provinsi Nusa Tenggara Barat. Ketiga, untuk mengukur dan menganalisis dominasi pengaruh di antara variabel Kemampuan dan Motivasi Kerja terhadap Kinerja Pegawai Negeri Sipil pada Dinas Pendidikan dan Kebudayaan Provinsi Nusa Tenggara Barat.

\section{B. METODE PENELITIAN}

Penelitian ini merupakan jenis penelitian kuantitatif, ditinjau dari tingkat ekspansi penelitian ini merupakan penelitian asosiatif. Penelitian asosiatif terdiri dari hubungan kausal, hubungan simetris, dan hubungan interaktif atau timbal balik. Hubungan kausal merupakan hubungan yang sifatnya sebab-akibat, salah satu variabel (independen) mempengaruhi variabel yang lain (dependen). Hubungan simetris adalah hubungan antara dua variabel yang bersifat sejajar atau terjadinya bersamaan. Hubungan interaktif atau timbal balik atau bisa juga di sebut hubungan respirokal adalah hubungan yang variabelnya saling mempengaruhi dan tidak diketahui variabel independen maupun dependennya [12].

Dalam penelitian yang dilakukan ini, metode penelitian yang dilakukan adalah asosiatif dengan bentuk hubungan kausal. hubungan kausal adalah hubungan yang bersifat sebab akibat. Jadi, disini ada variabel independen (mempengaruhi) dan variabel dependen (dipengaruhi)[13]. Hal ini berarti penelitian berfokus pengaruh kemampuan dan motivasi terhadap kinerja pegawai pada Dinas Pendidikan dan Kebudayaan Provinsi Nusa Tenggara Barat.

Untuk menghimpun data-data dalam penelitian ini, maka ditetapkan populasi. populasi adalah wilayah generalisasi yang terdiri atas obyek/subyek yang mempunyai kualitas dan karakteristik tertentu yang ditetapkan oleh peneliti untuk dipelajari dan kemudian ditarik kesimpulannya [13]. Populasi dalam penelitian ini adalah 128 orang pegawai tata usaha yang bekerja di bawah Dinas Pendidikan dan Kebudayaan Provinsi Nusa Tenggara Barat.

Untuk mengetahui tanggapan responden terhadap variabel yang dinilai, digunakan alat analisis skala likert, dimana responden menyatakan tingkat setuju atau tidak setuju (baik atau tidak baik) mengenai berbagai pernyataan tentang perilaku, objek, orang, atau kejadian. Skala likert dipergunakan untuk mengidentifikasi sautu pendapat, pernyataan, sikap, maupun prilaku dari seseorang maupun sekelompok orang terhadap suatu geala yang diteliti [12]. Untuk setiap alternatif jawaban yang diberikan diberikan bobot $1-5$.

Analisis Regresi Linier Berganda digunakan untuk menganalisis besarnya pengaruh variabel independen terhadap variabel dependen dengan analisis regresi berganda digunakan apabila jumlah variabel independennya minimal 2 (dua). Regresi berganda yaitu alat analisis yang digunakan untuk meramalkan bagaimana keadaan (naik turunnya) variabel dependen, bila dua atau lebih variabel independen sebagai faktor prediktor yang dimanipulasi (dinaik-turunkan nilainya) [12]. Dalam penelitian ini menggunakan dua prediktor yaitu motivasi dan kemampuan dengan persamaan sebagai berikut [12]:

$$
\begin{aligned}
& Y=a+b_{1} X_{1}+b_{2} X_{2}+e \\
& \text { Keterangan : } \\
& Y=\text { Kinerja Pegawai } \\
& a=\text { Konstanta } \\
& X_{1}=\text { Kemampuan } \\
& X_{2}=\text { Motivasi } \\
& b_{1}=\text { Koefisien regresi untuk } X_{1} \\
& b_{2}=\text { Koefisien regresi untuk } X_{2} \\
& e=\text { error }
\end{aligned}
$$

Metode pengujian ini digunakan untuk menguji derajat keyakinan antara variabel yang diteliti secara parsial, artinya untuk mengetahui pengaruh yang signifikan secara parsial dari motivasi dan Kemampuan terhadap kinerja pegawai, dengan persamaan sebagai berikut:

$$
\text { thitung }=\frac{b_{1}}{s e\left(b_{1}\right)}
$$

Dimana:

thitung $=$ uji koefisien regresi ganda secara persial

se $\quad=$ standar eror

b1 $\quad=$ nilai koefisien $X$ 
Untuk menunjukkan seberapa pengaruh satu variabel independen secara individual dengan cara membandingkan $t$ hitung dengan $t$ tabel pada tingkat kepercayaan dipilih $\alpha=0,05$ dengan kriteria pengujian sebagai berikut :

1. Jika $\mathrm{t}$ hitung $>\mathrm{t}$ tabel atau $-\mathrm{t}$ hitung $<-\mathrm{t}$ tabel maka Ho ditolak.

2. Jika $\mathrm{t}$ hitung $\leq \mathrm{t}$ tabel maka Ho diterima, Ha ditolak.

3. Untuk menguji $\mathrm{t}$ hitung, dilakukan dengan program SPSS.

\section{HASIL DAN PEMBAHASAN}

\section{Deskripsi Variabel Penelitian}

Kemampuan pegawai adalah tanggapan responden terhadap kecakapan yang dimiliki pegawai dalam melaksanakan tugas keprofesionalannya pada Dinas Pendidikan dan Kebudayaan Provinsi Nusa Tenggara Barat. Item pertanyaan atau pernyataan yang diajukan untuk variabel Kemampuan Pegawai sebanyak 9 item. Rata-rata total dari Kemampuan berdasarkan tanggapan responden sebesar 4,18 dengan kriteria kompeten. Kriteria ini menunjukkan bahwa kemampuan yang dimiliki oleh pegawai dalam melaksanakan tugas keprofesionalannya sudah mencapai tingkat kompeten. Meskipun terdapat beberapa pegawai yang tidak sesuai dengan Kemampuannya, tetapi yang sesuai dengan hKemampuan di bidang manajerial lebih dominan sehingga nampak bahwa pegawai lebih nampak memiliki Kemampuan dalam bekerja.

Motivasi kerja merupakan tanggapan responden terhadap dorongan yang dimiliki oleh seorang pegawai untuk mencapai tujuan Dinas Pendidikan dan Kebudayaan Provinsi Nusa Tenggara Barat. Item pertanyaan atau pernyataan yang diajukan untuk variabel Kemampuan Pegawai sebanyak 6 item. Ratarata total dari motivasi kerja menunjukkan rata-rata total sebesar 3,98 dengan kriteria yang menunjukkan bahwa pegawai memiliki motivasi yang tinggi dalam melaksanakan pekerjaan dan tanggung jawabnya. Hal ini sangat berdampak positif karena akan memberikan sumbangan terbaik dalam bekerja terutama dalam mencapai tujuan Lembaga.

Kinerja pegawai adalah penilaian atasan langsung terhadap standar kinerja Pegawai Dinas Pendidikan dan Kebudayaan Provinsi Nusa Tenggara Barat dalam melaksanakan pekerjaannya. Item pertanyaan atau pernyataan yang diajukan untuk variabel Kemampuan Pegawai sebanyak 8 item. Rata-rata total dari kinerja berdasarkan tanggapan responden sebesar 4,28 dengan kriteria sangat baik. Kriteria ini menunjukkan bahwa tingkat kinerja pegawai pada Dinas Pendidikan dan Kebudayaan Provinsi Nusa Tenggara Barat berada pada kriteria sangat baik. Penilaian atasan sangat baik terhadap standar kinerja yang terdiri Proses kerja, Kondisi pekerjaan, Waktu yang dipergunakan dalam melaksanakan pekerjaan, Hasil kerja sesuai dengan ketetapan atau standar pekerjaan, Kualitas pekerjaan, Tingkat kemampuan dalam bekerja, Jalinan kerja sama dengan rekan kerja, dan Kekompakan dengan rekan kerja. Pihak manajemen harus lebih memperhatikan kembali setiap kinerja pegawainya.[14]

\section{Hasil Analisis Regresi Liner Berganda}

Analisis regresi berganda digunakan untuk mengetahui pengaruh motivasi kerja dan Kemampuan terhadap kinerja pegawai pada Dinas Pendidikan dan Kebudayaan Provinsi Nusa Tenggara Barat. Untuk melihat bagaimana fungsi regresi yang dapat dirumuskan dari hasil perhitungan dengan SPSS 18.0 maka dapat dilihat pada tabel 2., di bawah ini.

Tabel 2

Signifikansi Parameter Individual

\begin{tabular}{llcc}
\hline \multirow{2}{*}{ Model } & \multicolumn{2}{c}{ Unstandardized } \\
& & Coefficients & \\
\multirow{2}{*}{1} & (Constant) & B & Std. Error \\
& Motivasi kerja & 1,767 & 0.072 \\
& Kemampuan & 0,473 & 0.067 \\
\hline
\end{tabular}

a Dependent Variable: Kinerja pegawai

Melalui tabel 2., di atas maka dapat dirumuskan fungsi dari regresi linier sebagai berikut :

\begin{tabular}{ll}
\multicolumn{3}{c}{$\mathrm{Y}=1,767+0,473 \mathrm{X}_{1}+0,134 \mathrm{X}_{2}$} \\
Keterangan : \\
Konstanta $=1,767$ & $\mathrm{Y}=$ Kinerja pegawai \\
$\mathrm{b}_{1} \quad=0,473$ & $\mathrm{X}_{1}=$ Kemampuan \\
$\mathrm{b}_{2} \quad=0,134$ & $\mathrm{X}_{2}=$
\end{tabular}

Fungsi linier tersebut di atas dapat dijabarkan sebagai berikut. Nilai konstanta sebesar 1,767 berarti bahwa apabila masing-masing variabel independen yaitu dan Kemampuan dan motivasi kerja memiliki nilai o, maka kinerja pegawai pada Dinas Pendidikan dan Kebudayaan Provinsi Nusa Tenggara Barat bernilai 1,767. Hal ini bermakna bahwa kinerja pegawai ketika tidak adanya Kemampuan dan tidak adanya motivasi kerja adalah sebesar 1,767 .

Koefisien regresi dari motivasi kerja $\left(b_{1}\right)$ yang bernilai sebesar 0,473 berarti bahwa apabila variabel Motivasi kerja $\left(\mathrm{X}_{2}\right)$ nilainya nol (o) dan variabel Kemampuan $\left(\mathrm{X}_{1}\right)$ memiliki nilai sebesar 1, maka kinerja pegawai akan mengalami kenaikan sebesar 0,473. Koefisien regresi Kemampuan $\left(b_{1}\right)$ yang bernilai positif ini bermakna bahwa semakin tinggi Kemampuan pegawai maka kinerja pegawai tersebut akan semakin tinggi juga. Begitupula sebaliknya semakin rendah Kemampuan pegawai maka kinerja pegawai tersebut akan semakin rendah. 
Koefisien regresi dari Motivasi kerja $\left(\mathrm{b}_{2}\right)$ yang bernilai 0,134 menjelaskan bahwa apabila variabel Kemampuan $\left(\mathrm{X}_{1}\right)$ nilainya nol (o) dan variabel Motivasi kerja $\left(\mathrm{X}_{2}\right)$ memiliki nilai sebesar 1, maka kinerja pegawai mengalami kenaikan sebesar 0,134 . Koefisien regresi Motivasi kerja $\left(\mathrm{b}_{2}\right)$ yang bernilai positif ini bermakna bahwa semakin tinggi Motivasi kerja pegawai maka kinerja pegawai tersebut akan semakin tinggi. Begitu pula sebaliknya, semakin rendah Motivasi kerja pegawai maka kinerja pegawai tersebut akan semakin rendah.

\section{Hasil Uji Signifikansi (Uji t)}

Untuk melihat bagaimana pengaruh secara parsial antara motivasi kerja dan Kemampuan terhadap kinerja pegawai pada Dinas Pendidikan dan Kebudayaan Provinsi Nusa Tenggara Barat digunakan uji t. Dari informasi tabel 4.14., maka dapat dilihat bahwa nilai $\mathrm{t}$ hitung positif untuk variabel Kemampuan sebesar 5,867 dan $t$ hitung positif untuk variabel Motivasi kerja sebesar 2,295 . Untuk menemukan jawaban atas hipotesis yang ada maka perlu dibandingkan antara $t$ hitung dengan $\mathrm{t}$ tabel.

\section{Tabel 3}

Hasil Uji $t$ variabel bebas terhadap variabel terikat

\begin{tabular}{lccccc}
\hline \multirow{2}{*}{ Model } & \multicolumn{2}{c}{$\begin{array}{c}\text { Understandarized } \\
\text { Coefficients }\end{array}$} & $\begin{array}{l}\text { Standarized } \\
\text { Coefficients }\end{array}$ & t & Sig. \\
\cline { 2 - 6 } & $\mathrm{B}$ & $\begin{array}{c}\text { Std. } \\
\text { Eror }\end{array}$ & Beta & & \\
\hline 1 (Constant) & 1,767 &, 270 & & 6,548 &, 000 \\
\hline Kemampuan &, 473 &, 081 &, 506 & 5,867 &, 000 \\
\hline $\begin{array}{l}\text { Motivasi } \\
\text { Kerja }\end{array}$ &, 134 &, 059 &, 198 & 2,295 &, 023 \\
\hline
\end{tabular}

aDependent Variable: Kinerja Pegawai

Dengan menggunakan tingkat keyakinan 95\% dimana $\mathrm{a}=5 \%$, df (degree fredom) $\mathrm{n}-\mathrm{k}-1=128-2-1=125$, sehingga diperoleh hasil untuk t tabel sebesar 1,979 (pada lampiran 7). Sehingga karena $t$ hitung motivasi kerja $>t$ tabel $(5,867>1,979)$ dan $t$ hitung Kemampuan $>$ t tabel $(2,295>1,979)$ maka dapat disimpulkan bahwa terdapat pengaruh yang signifikan secara parsial dari Kemampuan dan motivasi kerja terhadap kinerja pegawai pada Dinas Pendidikan dan Kebudayaan Provinsi Nusa Tenggara Barat.

Hasil penelitian menunjukkan bahwa motivasi kerja dan kemampuan berpengaruh signifikan terhadap kinerja pegawai pada Dinas Pendidikan dan Kebudayaan Provinsi Nusa Tenggara Barat. Hal ini diperkuat oleh pendapat Mathis dan Jackson bahwa faktor-faktor utama yang mempengaruhi kinerja individual adalah tingkat usaha yang dicurahkan atau motivasi dan kemampuan individual untuk melakukan pekerjaan tersebut. [15];[16];[17] Motivasi merupakan kekuatan yang mendorong seorang pegawai untuk mengarahkan perilakunya sehingga dapat mencapai kinerja. Motivasi kerja memegang peranan penting dalam menentukan berhasil tidaknya seseorang dalam melaksanakan tugas yang dibebankan kepadanya. [18];[19] Demikian pula lainnya menjelaskan bahwa motivasi akan menyebabkan, menyalurkan, dan mendukung perilaku manusia supaya mau bekerja.[20];[21]

\section{SIMPULAN DAN SARAN}

Berdasarkan hasil penelitian ini menunjukkan bahwa 1. Berdasarkan uji t ditemukan bahwa terdapat pengaruh yang signifikan secara parsial dari Kemampuan terhadap kinerja pegawai pada Dinas Pendidikan dan Kebudayaan Provinsi Nusa Tenggara Barat. 2. Berdasarkan uji t ditemukan bahwa terdapat pengaruh yang signifikan secara parsial damotivasi kerja terhadap kinerja pegawai pada Dinas Pendidikan dan Kebudayaan Provinsi Nusa Tenggara Barat. 3. Berdasarkan standardized coefficient beta yang menunjukkan bahwa Kemampuan memiliki pengaruh yang dominan terhadap kinerja pegawai pada Dinas Pendidikan dan Kebudayaan Provinsi Nusa Tenggara Barat.

Adapun beberapa saran yang dapat direkomendasikan berdasarkan hasil penelitian adalah : 1. Pegawai yang masih kurang kompeten perlu untuk diberikan pendidikan dan pelatihan sesuai dengan bidang pekerjaannya sehingga kemampuan yang dimiliki oleh pegawai bisa mendukung perkembangan organisasi. 2. Motivasi kerja seorang pegawai sangat ditentukan oleh pimpinannya. Untuk meningkatkan motivasi pegawai yang masih rendah pimpinan perlu untuk meningkatkan keinginan untuk melakukan yang terbaik dalam melaksanakan tugas kepada negara, meningkatkan keinginan untuk membantu memecahkan masalah yang timbul dalam instansi, melakukan perbuatan baik bagi masyarakat adalah hal penting bagi pegawai, mendahulukan tugas daripada kepentingan sendiri, dan memberikan pelayanan publik yang berarti adalah hal yang sangat penting bagi pegawai. 3. Bagi para peneliti yang tertarik dengan judul yang sama, subjek penelitian juga perlu diperluas dengan jumlah responden lebih besar sehingga ketepatan model dengan variasi pengaruhnya bisa lebih tinggi lagi dalam mempengaruhi kinerja individu.

\section{DAFTAR RUJUKAN}

[1] S. Wibowo, "Manajemen Kinerja-Edisi ketiga, Jakarta: PT," Raja Graf. Persada, 2010.

[2] M. Armstrong and A. Baron, Performance management: The new realities. State Mutual Book \& Periodical Service, 1998.

[3] M. A. A. A. Prabu, "Manajemen Sumber Daya Manusia Perusahaan, Edisi Pertama, PT," Remaja Rosdakarya, Bandung, 2001.

[4] C. Bao and I. Nizam, "The impact of motivation on employee performance in the electronics industry in CHINA," Int. J. Account. Bus. Manag., vol. 3, no. 2, pp. 29-45, 2015.

[5] J. L. Gibson, J. M. Ivancevich, J. H. Donnely, and A. Dharma, Organisasi: perilaku, struktur, proses. Penerbit Erlangga, 1987. 
[6] D. C. McClelland and R. E. Boyatzis, "Leadership motive pattern and long-term success in management.," J. Appl. Psychol., vol. 67, no. 6, p. 737, 1982.

[7] J. M. Ivancevich, M. T. Matteson, and R. Konopaske, "Organizational behavior and management," 1990.

[8] A. Jannah, B. T. Fitria, and E. Hadiat, "Pengaruh Kompensasi, Pengembangan Karier, Dan Disiplin Kerja Terhadap Kinerja Pegawai Dinas Pendapatan Daerah Kota Cimahi,” J. Ekon. Bisnis Entrep., vol. 8, no. 2, pp. 99-110, 2014.

[9] Y. Ilyas, "Kinerja: Teori, penilaian dan penelitian," Depok Pus. Kaji. Ekon. Kesehat. FKMUI, 2002.

[10] S. Rahayuningsih, "Pengaruh Kompetensi, Kompensasi Dan Motivasi Terhadap Kinerja Karyawan (Studi Pada PT. Pisma Garment Demak Jawa Tengah),” 2018.

[11] S. D. Sudarwati, "Pengaruh motivasi, disiplin kerja dan kompetensi terhadap kinerja pegawai dinas pendidikan Kabupaten Sragen," J. Paradig. Univ. Islam Batik Surakarta, vol. 12, no. 1, p. 116176, 2014.

[12] Sugiyono, Metode Penelitian Bisnis. Bandung: Alfabeta, 2010.

[13] Sugiyono, Metode Penelitian Kuantitatif, Kualitatif, dan $R \& D .2013$.

[14] C. Orocomna, T. M. Tumbel, and S. I. Asaloei, "Pengaruh Motivasi Kerja Terhadap Kinerja Karyawan Pada PT. TASPEN (Persero) Cabang Manado,” J. Adm. BISNIS, vol. 7, no. 1, pp. 66-72, 2018.

[15] R. L. and J. H. J. Mathis, Manajemen Sumber Daya Manusia, Edisi 1o, Edisi 10,. Jakarta: Salemba Empat, 2006.

[16] Z. Imatama, "Pengaruh Kompetensi dan Motivasi Terhadap Kinerja Pegawai pada PDAM Tirtanadi Cabang Padang Bulan.” 2012.

[17] R. Anjayani, "Pengaruh Motivasi Kerja, Disiplin Kerja, dan Kompensasi Terhadap Kinerja Karyawan pada Home Industry Adi Jaya Konveksi di Desa Kedungpuji Kecamatan Gombong Kabupaten Kebumen.” Pendidikan Ekonomi-FKIP, 2017.

[18] T. A. Robbins, S. dan Judge, Perilaku Organisasi, Organizational Behaviour, Buku Terjemahan. Jakarta: Gramedia, 2008.

[19] N. Nurhaedah, S. Mardjuni, and H. M. Y. Saleh, "Pengaruh Kemampuan Kerja dan Motivasi Kerja Terhadap Kinerja Karyawan PT. Semen Tonasa Kabupaten Pangkep," Publik (Jurnal Ilmu Adm., vol. 7, no. 1, pp. 11-21, 2018.

[20] M. S. P. Hasibuan and H. M. S. P. Hasibuan, Manajemen sumber daya manusia. Bumi Aksara, 2016.

[21] T. Triyanto, "Pengaruh Pendidikan, Motivasi Kerja dan Kemampuan Kerja terhadap Kinerja Pegawai pada Dinas Pendapatan Pengelolaan Keuangan dan Asset Daerah Kabupaten Grobogan," J. STIE Semarang, vol. 8, no. 3, p. 131377, 2016. 